\title{
Nasopharyngeal Cancer Clinical TNM Finding v8
}

National Cancer Institute

\section{Source}

National Cancer Institute. Nasopharyngeal Cancer Clinical TNM Finding v8. NCI

Thesaurus. Code C132793.

A clinical finding about one or more characteristics of nasopharyngeal cancer, following the rules of the TNM AJCC V8 classification system. 